\title{
Sedimentation on intertidal mudflats in the lower part of macrotidal estuaries: Sedimentation rhythms and their preservation
}

\author{
Deloffre $\mathrm{J}^{\mathrm{a}, *}$, Verney $\mathrm{R}^{\mathrm{b}}$, Lafite $\mathrm{R}^{\mathrm{a}}$, Lesueur $\mathrm{P}^{\mathrm{c}}$, Lesourd $\mathrm{S}^{\mathrm{d}}$, Cundy A. $\mathrm{B}^{\mathrm{e}}$
}

\begin{abstract}
aUMR CNRS 6143, Morphodynamique continentale et côtière, Université de Rouen, 76821 Mont-Saint-Aignan Cedex, France

'IFREMER, Dyneco Physed, BP 70, 29280 Plouzané, Cedex, France

'UMR CNRS 6143, Morphodynamique continentale et côtière, Université de Caen, 14000 Caen Cedex, France

'UMR CNRS 8013, ELICO, Université du Littoral-Côte d'Opale, 62930 Wimereux, France

${ }^{\mathrm{e}}$ Coastal and Estuarine Research Group, School of Life Sciences, University of Sussex, Falmer, Brighton, BN1 9QJ, U.K.
\end{abstract}

*: Corresponding author : Deloffre J. e-mail : julien.deloffre@univ-rouen.fr

\begin{abstract}
:
The objective of this study is to propose an original approach to the analysis of the formation of intertidal rhythmites, their preservation, and the evaluation of sedimentation rates on estuarine mudflats. Three mudflats, one from each of three estuaries, were analysed using a combination of long-term ( $>$ a year), high-frequency (1 burst/10 or $20 \mathrm{~min}$ ), and high-resolution $(0.2 \mathrm{~cm})$ altimeter datasets and X-ray images of sediment cores collected during topographic surveys. The results highlight the roles played by sediment supply, hydrodynamics, and morphology of the lower estuaries on the sedimentation rhythms. While the sediment-starved Medway estuary (Kent, UK) remains stable at different time-scales, the annual sedimentation rates on the sheltered Authie mudflat (Pas-deCalais, France) and the open Seine mudflat (Normandy, France) are relatively high at 18 and $15 \mathrm{~cm}$ yr- 1, respectively. On the Authie mudflat, sedimentation rhythms correspond to the semi-lunar cycle, with a good correlation between tidal range and deposit thickness. Sedimentation occurs at the beginning of the recovery (mean value of $0.25 \mathrm{~cm}$ per semi-diurnal cycle), and is not disturbed by wind-induced waves. In the lower Seine estuary, semi-diurnal mechanisms of deposition occur mainly when the mudflat is covered by a minimal water height (tidal range threshold value $=7.1 \mathrm{~m}$ ). Sedimentation rhythms are discontinuous and deposition occurs only during the highest spring tides. Mean deposit thickness is $0.6 \mathrm{~cm}$ per semi-diurnal cycle, controlled by the turbidity maximum and the long high tide slack $(2-3 \mathrm{~h})$. The fluid mud is sensitive to wind-waves in this open funnel-shaped estuary, which undergoes wind-induced erosion $(0.2$ to $2 \mathrm{~cm})$ about 10 times per year.
\end{abstract}

Comparison of altimeter datasets and lithology of the sediments cored at the same points provided improved understanding of the sediment record rhythms and the sedimentation events. On the sediment-starved Medway mudflat, the result of sediment processes is a single superficial lamina. The elementary deposit in the Authie bay corresponds to a semi-lunar-linked layer, typical of sheltered environments. On the lower Seine mudflat, sedimentation rhythms are linked to the highest spring tides (i.e., the lunar cycle), resulting from increased sediment availability related to the high suspended matter concentration in the turbidity maximum. These results underline the complex response of intertidal mudflats to hydrodynamics and sediment supply conditions, from the semi-diurnal to the annual scales.

Keywords: morphology; mud; rhythmites; altimeter; X-ray imagery; macrotidal estuary 
Tidal flats in marine or brackish parts of estuarine systems have been the focus of numerous morpho-sedimentary studies (e.g. Amos, 1995; Perillo, 1995; Black et al., 1998; Dyer, 1998 and Dyer et al., 2000a, 2000b). Recent works using altimeter measurements have allowed a more detailed understanding of the morphological evolution of intertidal mudflats over varying timescales. These studies underline the importance of cyclical evolution of intertidal mudflat elevation and morphology, controlled either by tidal forcing (Christies et al., 1999; Pritchard et al., 2002; Deloffre et al., 2006) or by high river discharge (Deloffre et al., 2005). Wind events (Bassoullet et al., 2000, Fan et al., 2006) and biological activity (e.g., Gouleau et al., 2000; Andersen and Pejrup, 2002) increase the complexity of the behaviour of these environments. Similar controls have been identified in studies of cyclic sedimentary facies (i.e. tidal rhythmites) in ancient and recent environments (e.g: Dalrymple et al., 1978; Tessier, 1993; Kvale et al., 1994; Archer, 1995; Tessier et al., 1995; Choi et Park, 2000; Stupples, 2002).

The sedimentological analysis of cyclical or rhythmic sedimentation on intertidal mudflats in estuarine systems is frequently complicated however by the relative homogeneity of the material that settles, intensive bioturbation, and physical removal of settled material as a result of highenergy events in the water column leading to erosion (West and West, 1991; Kirby et al., 1993; Schoellehammer, 1996; Bassoullet et al., 2000). Here we combine high-resolution altimeter datasets with sediment core analysis to examine the sedimentary behaviour of intertidal mudflats in the lower part of three contrasting macrotidal estuaries: a mudflat in a typical sheltered bay (the Authie, France), a relatively stable mudflat in a sediment-starved estuary (the Medway, U.K.), and a mudflat in a system with a highly concentrated turbidity maximum (the Seine, France). The objective of this paper is to analyse the sediment processes associated with the different cycles on the mudflats and to compare them on the basis of a long-term (at least one year), high-frequency and high-resolution topographic study carried out by acoustic altimeter, and on lithologic records in sediment cores collected from each of the sites during the same survey periods. The altimeter 
datasets provide information on the role played by the morphology of the intertidal mudflats and the availability of sediment supply. The comparison of altimeter data and lithologic variations allows investigation of the occurrence and the preservation rates of tidal-induced mudflat deposits (i.e. percentage of sedimentary structures preserved). The occurrence and preservation of the laminae is mainly controlled by the sedimentation and the erosion rates, the sediment properties, the dewatering, the erosion induced by high energy events (boat passage or wind events) and bioturbation.

\section{Study sites}

In order to obtain contrasting sedimentary trends, the sampling strategy was to study estuarine system characterized by different morphological and sedimentological features at the mouth (Fig. 1 and Table 1). The mudflat in the Authie bay corresponds to a sheltered system combined to continuous fine-sediment inputs. The Seine one is an opened system associated with turbidity maximum inputs. The Medway mudflat corresponds to a sheltered system in a sedimentstarved estuary.

The Authie bay is a macrotidal system (maximum tidal range of $8.5 \mathrm{~m}$ at its mouth) located in the northern part of France (Fig. 1B). The mean annual discharge of the Authie River is $10 \mathrm{~m}^{3} \cdot \mathrm{s}^{-1}$, and the river has a $985 \mathrm{~km}^{2}$ catchment area. This estuarine system is rapidly filling with silting, but a chief feature is the penetration of a substantial sand fraction originating from the English Channel (Anthony and Dobroniak, 2000). Morphologically, the Authie consists of a bay protected by a sand bar (located in subtidal to supratidal domains) at its mouth, which shelters the estuary from storm swells (Fig. 1B). The principal hydrodynamic feature is the rapid filling of the bay by the tide: during low tide, most of the estuary, except the main channel, is sub-aerially exposed, and during the flood period there is significant resuspension of fine sediment. The Authie bay is considered to be a relatively "natural estuary”, compared with other local systems, although some polders have 
been constructed, inducing a seaward salt marsh progression and increased sedimentation (Anthony and Dobroniak, 2000).

The macrotidal Seine estuary (maximum tidal range of $8.0 \mathrm{~m}$ at its mouth) is located in the northwestern part of France (Fig. 1C). It is one of the largest estuaries on the Northwestern European continental shelf, with a catchment area of more than $79,000 \mathrm{~km}^{2}$. The mean annual Seine river flow, computed for the last 50 years, is $450 \mathrm{~m}^{3} . \mathrm{s}^{-1}$. During the last two centuries, the Seine estuary has been greatly altered by human activity (Avoine et al., 1981; Lafite and Romaña, 2001; Lesourd et al., 2001). Intensive engineering works were undertaken between Rouen and Le Havre to improve navigation. As a result, the lower Seine river was changed from a dominantly natural system to an anthropogenically-controlled one (Lesourd et al., 2001). Despite the highly dynamic nature of the system, tidal flats and salt marshes are still developed in the lower estuary, however the intertidal surface area has drastically decreased during the last 30 years (Lesourd, pers. comm.). The lower estuary is characterized by the presence of a distinct estuarine turbidity maximum (Avoine et al., 1981), which has a pronounced control on the sedimentation patterns on intertidal mudflats at the estuary mouth (Deloffre et al., 2006). One of the principal hydrodynamics features in the Seine estuary is a 3-hour high-water slack period that can occur at the mouth. The funnelshaped estuary is exposed to the prevailing SSW winds, which make the intertidal regions at the mouth subject to erosion under the combined effect of waves and currents (Verney et al., 2007).

The macrotidal Medway estuary (maximum tidal range of $\sim 5.6 \mathrm{~m}$ at the mouth) is located in the southeastern part of England (Fig. 1A) and today forms part of the wider Thames estuary system. Medway river flow is $35 \mathrm{~m}^{3} \cdot \mathrm{s}^{-1}$, and the river has a $1,750 \mathrm{~km}^{2}$ catchment area. Extensive intertidal flats and salt marsh islands characterize the lower part of the estuary, although much of the salt marsh has been lost through the removal of material for brick-making. From a sedimentological point of view, the Medway exhibits two distinct characteristics: the absence of sands on intertidal mudflats and the reworking of fine particles within the estuary. This last feature 
120 is a consequence of the absence of significant external sediment supply. While some mudflats are 121 slowly accreting, erosion processes dominate (Burd, 1989; Kirby, 1990; Pye and French, 1993).

\section{Materials and methods}

\section{Oceanographic instrument deployments}

A similar sampling strategy was used for each of the three mudflats. A Micrel ALTUS altimeter was placed at a similar elevation in each estuary (4-6.5 m above the lowest sea level, i.e., on the middle slikke). This instrument measures bed elevation at high frequency (1 acoustic pulse every 10 minutes on the Authie and Seine mudflats, and every 20 minutes on the Medway mudflat), with high resolution $(0.2 \mathrm{~cm})$ and high accuracy $(0.06 \mathrm{~cm})$. The altimeter is composed of a $2 \mathrm{MHz}$ acoustic transducer, which measures the time required for an acoustic pulse to travel from the mudflat surface to the transducer; which was fixed at a height of $\sim 22 \mathrm{~cm}$ above the sediment surface. Pairs of poles were deployed along a cross-section on each mudflat. Data collected by the altimeter deployed in the middle of the cross-section is representative of the erosion-deposition processes along the section (Bassoulet et al., 2000; Deloffre et al., 2005).

The datasets acquired by the altimeter on the Medway and Seine estuaries were corrected for salinity and temperature effects using data from autonomous buoys near the studied sites (Deloffre et al., 2006) and Coppens (1981) equation for the speed of sound in water. However, for the Authie, these corrections could not be made because of the absence of an estuarine network. In order to identify seasonal trends in the sedimentary behaviour of each intertidal mudflat, the altimeter was deployed for at least one year at each site: 23/09/02-28/11/04 (Authie), 20/06/03-18/08/05

141 (Medway), and 25/07/01-04/05/03 (Seine). Annual variations in bed level indicated that the most suitable period for sediment deposition was spring tide, hence additional equipment deployments were carried out during these periods.

The prevailing near-bed current velocities at the sites were measured during several spring semi-diurnal tidal cycles under low river flow conditions using a 6-MHz Nortek Acoustic Doppler 
Velocimeter (ADV) (Kim et al., 2000). The ADV measurement cell was located $15 \mathrm{~cm}$ from the transmitter, and was set to measure at a height of $7 \mathrm{~cm}$ above the sediment-water interface. This instrument acquires 3D current velocities near the bed at a 32-Hz frequency. These high-resolution measurements allow the calculation of bottom shear stress. The turbulent kinetic energy (TKE) method, judged to be the most suitable to estimate the turbulence generated by tidal currents and wind-induced waves on intertidal mudflats (Voulgaris and Townbridge, 1998; Kim et al., 2000). However wave-current interactions are incorporated in the TKE shear stress calculations. The method used in this study refers to the parametric Wave-Current Interaction (WCI) model proposed by Soulsby (1995). This model was applied here ( $\tau$ wc) in order to remove wave-current interactions in the shear stress calculations (Verney et al., 2007). The backscatter signal recorded by the ADV allowed estimation of the near-bed suspended solids concentration (SSC) (Kim et al., 2000). The relationship between ADV backscatter and SSC was derived at each site using surface sediment samples to minimize errors induced by grain-size variability (Voulgaris and Meyers, 2004).

\section{Sediment analyses}

In order to analyse the processes and to compare the evolution of the intertidal mudflats, superficial sediment properties were analysed. Surface sediments and short cores (length: 30 cm, diameter: $10 \mathrm{~cm}$ ) have been sampled during each field work period (i.e. every two months). The physical characteristics of the sediment were determined using standard sedimentological procedures. The water content was measured using a wet-dry weight technique (water content = water weight/dry weight $\mathrm{x}$ 100). The grain-size distribution (sand-to-clay fraction) was analysed using a Laser Beckman-Coulter LS 230. Organic matter content of the sediment was quantified by ignition loss at $525^{\circ} \mathrm{C}$.; Carbonate content was measured using a Bernard calcimeter.

The lithology of the cores was examined using the SCOPIX X-Ray imagery method developed by the Bordeaux I University (Migeon et al., 1999). This high-resolution instrument permits the observation of mm-thick layers of sediment (Lofi and Weber, 2001). 


\section{Results and interpretation}

\section{Sediment characteristics}

Carbonate content in surface sediments ranged between 9 and 15\% on the Medway mudflat. Higher carbonate content with much more variability was observed on the Authie and Seine mudflats, with carbonate contents between 25 and $50 \%$. The organic matter content of these superficial sediments, however, was similar at each site, ranging from $9.5 \%$ to $19 \%$. In each estuary, there is little temporal variability in grain-size characteristics. The primary grain-size modes are were: 20 and $40 \mu \mathrm{m}$ at the Medway site; 15, 40 and $90 \mu \mathrm{m}$ at the Seine site; and 40 and $90 \mu \mathrm{m}$ on the Authie site (Fig. 2). Thus the Authie and the Seine sediments generally are coarser than those for the Medway. The principal granulometric difference between the sites was seen in the sand fraction: a $200 \mu \mathrm{m}$-fraction over the Seine mudflat made up 5-15\% of the sediment, while on the Authie mudflat the fine-grained sediment was usually associated with a sand fraction of less than 10\% (modes: $200 \mu \mathrm{m}$ and more rarely $800 \mu \mathrm{m}$ ). In contrast, no sand was observed on the Medway mudflat (Fig. 2).

The main parameter varying over an annual scale was the water content. While this parameter was fairly constant over a 1-year monitoring period in the surface samples from the Medway estuary (70-95\%) and the Authie bay (65-90\%), it varied widely on the Seine mudflat (80200\%). Thus in this last estuary fluid mud occurs during periods of sedimentation. Variations in water content in the superficial sediments of the Seine mudflat result from deposition of fluid mud (water content $=200 \%$ ) on the mudflat, and from dewatering processes resulting from consolidation and from desiccation during neap tides. On the basis of laboratory experiments, Deloffre et al. (2006) have estimated the impact of dewatering on the altimeter dataset, and variations in bed elevation induced by dewatering have been removed from the raw altimeter dataset for the Seine estuary. The present altimeter dataset takes into account only erosion and sedimentation processes.

\section{Sedimentation rhythms and mechanisms}


An annual comparison of bed level measurements on the three intertidal mudflats is shown

in figure 3. Mudflats in the Authie and Seine estuaries received a net deposition of 15-18 $\mathrm{cm}_{\text {.year }}{ }^{-1}$ during the study whereas the Medway mudflat retained a relatively stable elevation throughout the year. Although net sedimentation rates over an annual timescale are similar in the Authie and Seine estuaries, sedimentation rhythms are different (Fig. 3).

On the Authie mudflat, topographical variations at a lower scale indicate that the sedimentation is controlled by the semi-lunar tidal cycle (Fig. 3, Fig 4A): bed level increases during spring tides, and then decreases or is stabilized during neap tides, when the water level is low on the mudflat or when the mudflat is subaerially exposed. For each spring tide cycle, the bed level increases leading to generally continuous sedimentation on the study area of Authie Bay throughout the year. The threshold between erosion and sedimentation phases corresponds to a water level of $110 \mathrm{~cm}$ on the mudflat, which in turn corresponds to a tidal range of $5.5 \mathrm{~m}$. This pattern induces a lag of a few days between the end of deposition and the maximum water level (Fig. 4A and 4B). The sedimentation rates observed on the mudflat range from 0.1 to $0.6 \mathrm{~cm}$ per semi-diurnal tidal cycle, with more resuspension of fine particles in the main channel of the bay during spring tides (at that time current velocities allow the reworking of fine-grained deposits), and a longer duration of immersion when there is a supply of fine particles (as opposed to during neap tides). Processes observed at the semi-diurnal scale (Fig. 5A) indicate that particles settle during flood periods, when

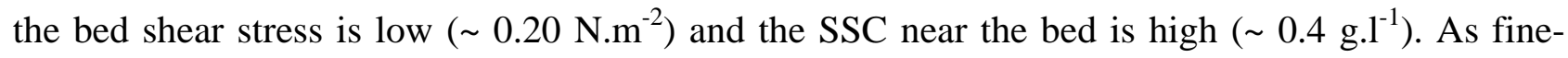
grained sediments settle out of suspension, the SSC progressively decreases. After 1 hour of immersion, most of the sediment have settled out of suspension, resulting in a 0.6-cm-thick deposit. During the high tide slack water and ebb periods, the SSC and the bottom shear stress are low, with mean values of 0.05 g.l $\mathrm{l}^{-1}$ and $0.25 \mathrm{~N} . \mathrm{m}^{-2}$, respectively. Twice during the survey, bottom shear stresses reached a value of $0.8 \mathrm{~N} \cdot \mathrm{m}^{-2}$ as a result of high energy events (Fig. 5A). However, no impact on the surface of the mudflat was observed during these two events, which each lasted 30 minutes. It is notable that during the second event, the water was lower on the mudflat and the SSC 
increased (Fig. 5A). This phenomenon might be linked to erosion of the upper part of the mudflat, which resulted from the combined effect of waves and tidal currents. However, at the station studied, the recently-settled sediment was not influenced by the waves: the Authie mudflat surface remained stable during these events. Apart from theses events, all the sedimentary mechanisms recorded are related to the repetition of semi-diurnal cycles during spring tides (Fig. 5A).

The annual sedimentation rate on the Seine estuary mudflat is $18 \mathrm{~cm}$ (Fig. 3), however, in contrast to the Authie mudflat, the main deposition phase occurs during the highest spring tides, i.e., according to the lunar cycle, when the water level is $>150 \mathrm{~cm}$ above the bed level at the station (corresponding to a tidal range of $7.1 \mathrm{~m}$ ). During these periods, the turbidity maximum reaches high concentrations (>1.95 g.l -1 $^{-1}$ and a maximum volume (Le Hir et al., 2001; Lesourd et al., 2001) in both the main channel (i.e., the navigation channel) and the northern channel, and the depositional rate on the mudflat is at a maximum (Deloffre et al., 2006). At these times, the sedimentation rate on the mudflat is high, from 0.3 to $0.8 \mathrm{~cm}$ per tide (Fig. 4B). As on the Authie mudflat, a lag between the depositional maximum and the water level maximum is observed (Fig. 4B). During periods of lower water level $(<150 \mathrm{~cm}$ water depth on the mudflat), the mudflat undergoes gradual erosion, with rates ranging between 0.02 and $0.085 \mathrm{~cm}$ during a semi-diurnal cycle. Over an annual timescale, the morphological evolution of the Seine mudflat corresponds to a few periods (6-10 per year) of high sedimentation, with increases in bed elevation of between 2 and $8 \mathrm{~cm}$, followed by long periods of slow erosion caused by tidal currents (Fig. 3).

At the semi-diurnal scale, particle settling occurs during high water slack periods (Fig. 5B). During the flood tide, when the Seine mudflat is covered, small wind waves occur, inducing a high bottom shear stress that reaches 0.8 to $1.0 \mathrm{~N} \cdot \mathrm{m}^{-2}$. These small wind waves occur even outside of storm periods. This bottom shear stress prevents deposition, and the SSC in the water column

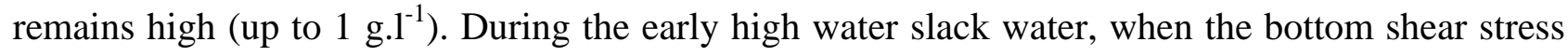
decreases $\left(\sim 0.20 \mathrm{~N} . \mathrm{m}^{-2}\right)$, the SSC also decreases as fine-grained material settles on the mudflat in a $1 \mathrm{~cm}$-thick layer (Fig. 5B). Once all the material has settled, the SSC in the water column is low. 
248 During the late slack and ebb periods, the topographic level decreases; this is interpreted as the 249 result of dewatering and erosion of the soft/fluid mud deposit by tidal currents. In the Seine estuary, 250 the duration of high water slack is up to 3 hours during spring tides, with a well-developed double 251 high tide that favours settling of fine particles and dewatering/consolidation processes just after 252 deposition.

The Medway mudflat has little topographical variations in comparison to the Seine and Authie mudflats (Fig. 4C): bed-level variations at the annual scale are $+/-1 \mathrm{~cm}$ (Fig. 3). This amplitude is consistent with results from earlier studies that report a low sediment supply in the Medway estuary (Kirby, 1990; Pye and French, 1993). This range of bed level elevation change is close to the altimeter accuracy, and thus is difficult to evaluate. However, on this mudflat the SSC is always low $\sim 0.1$ g.l $^{-1}$ (Fig. 5C), and the principal feature of the estuary is the lack of sediment supply. This low sediment supply, combined with the low impact of wind events (bottom shear stresses is always less than $0.20 \mathrm{~N} . \mathrm{m}^{-2}$ (Fig. 5C), leads to a topographic equilibrium at the annual scale (Fig. 3).

\section{Erosion events}

Altimeter measurements at a high resolution and high frequency were used to evaluate bed

level changes at the tidal scale, and determine the impact of wind-generated waves on the mudflat. Compared to continuous slow tidal erosion, the wind-induced reworking of intertidal mudflats occurs rapidly.

The Authie and Medway mudflats show no evidence of wind-generated erosion events (Fig.

3; Fig. 5B and 5C), consistent with the sheltered morphology of these estuaries. In contrast, the

Seine mudflat undergoes strong erosional phases induced by westerly to northwesterly swells and by local southerly to westerly waves in the Bay of the Seine (Lesourd et al., 2001). Such winds occur on the mudflat about 10 times per year, and are more common during the winter (Deloffre et al., 2006). At the study site, the amplitude of the wind-induced erosion was $0.2-2 \mathrm{~cm}$, corresponding to wind speed intensities ranging from 12 to $20 \mathrm{~m} . \mathrm{s}^{-1}$ (Deloffre et al., 2006). Adirect correlation 
between wind speed and erosion on the mudflat is difficult, however, as the consolidation state of the sediment must be taken into account. For example, for the same wind event, a fluid mud bottom (such as that found during a depositional period) will undergo more erosion than will a consolidated muddy bed (such as that found during tidal erosion periods).

\section{Coupling of altimeter datasets and lithologic analyses}

The SCOPIX X-ray images of cores allow the identification of physical structures, such as layers and surfaces, and biological structures, such as burrows, tracks, and shell remains, that make up the deposits. The images of the cores from the intertidal mudflats studied show that burrows always occur, and that shells are found at the Medway station only. As far as physical features, the Seine and Authie mudflat deposits are made up thin layers, whereas the Medway mudflat has no internal structure except for a single superficial layer. If only the data from the SCOPIX X-ray imagery is used, an interpretation of the sedimentary facies of the intertidal mudflats is difficult, as single layers can be interpreted as the result of semi-diurnal, semi-lunar, or lunar depositional cycles. To resolve this problem, for this study we interpreted sedimentary cores images in relation to the altimeter dataset. This approach allowed us to determine the duration of deposition for each layer, and to estimate deposition rates for each site, on the basis of the number and thickness of layers.

In the Authie mudflat, there is a great deal of bioturbation, mostly resulting from the activity of polychaetes (Nereis) at depth and of crustaceans (Corophium) in the superficial subsurface. Physical facies, however, also are easily observed at this site as thin layers of fine sediment (Fig. 4A). The occurrence of thin sediment layers is consistent with the observed bed-level variations (Fig. 4). At this site, where deposition is driven by the semi-lunar cycle, the depositional phases are recorded in the cores, and correspond to cm-thick layers; however, all the semi-lunar cycles are not preserved in the cores (Fig. 4A). This indicates that even in protected settings, water current velocities are high enough to rework some deposits corresponding to fortnightly cycles and, as a result, gaps occur on the neap-spring recording time. 
In the Seine estuary mudflat, freshly deposited sediments can clearly be identified in X-ray

301 images of cores collected a few days after the highest spring tide period (Fig. 4B). They are 302 characterized by erosion surfaces at the base of the elementary deposits, which result from tidal- or 303 wind-induced phases. Above this erosion surface, the fresh deposits are characterized by a low 304 consolidation state and low bulk density (water content on the order of 200\%). The fresh deposits 305 are seen in the positive X-ray images as light grey colours (Fig. 4B). The layer thicknesses 306 indicated by the altimeter dataset and the sedimentological variations in the cores are consistent: 307 when the core sampled a thickness of freshly deposited sediment of $\sim 2.5 \mathrm{~cm}$-thick, the altimeter 308 dataset indicated a bed-level elevation of $2.7 \mathrm{~cm}$ (Fig. 4B). The lithological analysis of the 309 uppermost part of the cores is more complicated, however, at sediment depths exceeding $10 \mathrm{~cm}$, 310 mainly because of strong mixing by bioturbation and the erosion of part of the deposits by waves 311 and/or tidal currents (Fig. 3).

No apparent physical structure is seen in the X-ray images of the sediment core collected 313 from the Medway mudflat. This is consistent with the monotonous altimeter record, which indicates 314 that the mudflat elevation is stable throughout the year (Fig. 3). The X-ray image of the core does, 315 however, show that the top centimetre of the sediment is very light, indicating that it corresponds to 316 material that is less consolidated than the underlying muddy sediment. This thin superficial layer 317 corresponds to the part of the sediments that is continuously reworked by tidal currents (Fig. 4C).

\section{General discussion}

The sedimentation processes on the three tidal mudflats examined here are strongly influenced by sediment supply and of the morphology of the estuary at various time-scales (Table2). No trend of net erosion or sedimentation occurs at the Medway station, whereas the mudflats examined in the

323 Seine and the Authie estuaries have a similar sedimentation rate at an annual scale (15-18 cm.year ${ }^{-}$ $\left.324^{1}\right)$. 
In the Medway estuary, Cundy et al. (2005) demonstrated that sedimentation rates are low and

that processes are reproducible. In this environment, hydrodynamic conditions such as tidal currents and turbulence are minimal and thus do not cause erosion of the mudflat. Furthermore, sedimentation phases are not recorded. No source of sediment has been identified for this mudflat. These patterns are consistent with literature citing the reworking of fine particles inside the estuary and little erosion of tidal flats and salt marshes (Burd, 1989; Kirby, 1990; Pye and French, 1993).

The morphology of the estuary mouth controls the impact of wind-generated waves. In the open lower Seine estuary, wind-generated waves result in rapid erosion $(0.2$ to $2 \mathrm{~cm})$ of the mudflat studied. Erosion by waves is controlled by wind direction and intensity, the water level on the mudflat, and the sediment characteristics. The erosion on the Seine mudflat during the survey occurred preferentially when the water level on the study site was low and was greater following the deposition of fresh, unconsolidated mud.

The sheltered Authie mudflat shows no evidence of wind-induced erosion: on this mudflat, tidal currents are the only cause of erosional phases at the study site.On the Seine and Authie mudflats, although long-term sedimentation rates are similar, the rhythms of deposition are different (Fig. 3, Table 2). On the Authie mudflat, sedimentation is continuous, with sedimentation rate controlled by the semi-lunar cycle. A linear relationship exists between the tidal ranges and the resulting deposit thickness, as determined from the altimeter data (Fig. 6). On the Seine estuary mudflat, no sedimentation occurs under neap- to medium spring-tide conditions. Rather, sedimentation on this mudflat occurs when a tidal range threshold value of $7.1 \mathrm{~m}$ is reached (Deloffre et al., 2006; Fig. 6). Sedimentation is thus discontinuous, occurring only during the higher spring tides, and leading to only a few $(<10)$ depositional episodes over the course of a year (Fig. 3 and Table 2).

Sedimentation on the Authie mudflat corresponds to a semi-lunar rhythm, typical of most modern sheltered mudflats. The lower Seine estuary mudflat, however, exhibits a distinct pattern of deposition-erosion. This unusual pattern is nota result of the altitude of the study site, as its 
elevation is the same as that of the Authie mudflat, and this pattern is recorded on other locations on the Seine slikke, including at lower altitudes (Deloffre et al., 2006). The difference between the rhythms of sedimentation on the Authie and Seine mudflats likely is linked to sediment availability and to sediment properties. On the Authie mudflat, the fine particles originate from the reworking of sediment from the lower parts of the slikke during the rapid filling of the estuary during the flood tide. During each spring period, the fine material is resuspended and sedimentation occurs on the mudflat at the location studied, which is on the middle slikke. In the Seine estuary, the delivery of sediment to the mudflat is related to the turbidity maximum (Deloffre et al., 2006). Because of the characteristics of the suspended particulates and the hydrodynamic conditions, development of the Seine estuary turbidity maximum is higher during tidal ranges that exceed $7.1 \mathrm{~m}$ (Avoine et al., 1981; Le Hir et al., 2001), which is the threshold value for deposition (Fig. 6). The control of sedimentation by the turbidity maximum also results in differences at the annual scale. Sedimentation rates are higher when river discharge is low, under which conditions the position of the turbidity maximum in the estuary is in the area of the mudflat (Lesourd et al., 2001; Le Hir et al., 2001). When river discharge is high, the turbidity maximum is expelled outside the estuary into the Bay of the Seine. During a lunar cycle (Fig. 3), high sedimentation rates result from some specific characteristics of the Seine estuary. Because of a high silt content (quartz, calcite) and a low clay mineral content (Lesourd, pers. comm.), the settling velocity of particles in the lower Seine estuary is higher $\left(\sim 1 \mathrm{~mm} . \mathrm{s}^{-1}\right)$ than in other estuarine settings (Delo and Ockenden, 1992). These high settling velocities combined with the long high tide slack (up to 3 hours) in the Seine estuary lead to the high sedimentation rates observed on the mudflat during the highest spring tides. These conditions result in the settling of fluid mud, a phenomenon that is observed only in this estuary among the three estuaries studied; thus on this mudflat, dewatering processes must be considered. The properties of cohesive material play an important role in controlling deposition (formation of laminae) and preservation of fine-grained sediments. The sediment of the Medway estuary mudflat, as analysed in the cores, is characterized by little variation in grain size. This feature, 
combined with insignificant sedimentation rates, results in the absence of physical structures in the cores collected from this mudflat. Sediment properties such as grain-size, water content, and settling velocities play a role in determining the thickness of deposits on intertidal mudflats. The depth of wind-induced erosion is related to the cohesion of surface sediments as well as to wave amplitude. As a result, erosion occurs on the open Seine mudflat where the mud is soft or even fluid (Fig. 4B), whereas on the sheltered Authie mudflat, where the sediment is coarser-grained and less fluid, only a small amount of wave-related erosion is observed (Fig. 5A).

Interpretation of tidal structures via investigation of the lithology of modern intertidal estuarine mudflats presents many challenges. By interpreting altimeter datasets and X-ray images concurrently, we can better understand the deposition and preservation of rhythmites in superficial deposits. On the Authie and Seine mudflats, where deposition is driven by tidal cycles (Fig. 3 and Table 2), sediment is deposited in mm- to cm-thick layers. However, because of the biological activity and the tidal or wind induced erosion occurring on these mudflats, rhythmites are rarely preserved in the cores. The comparison of several mudflat settings enhances the plurality of sedimentation tendencies, in particular when considering the superficial material (Table 2). In the uppermost $5 \mathrm{~cm}$ of the cores, the age of sediment for the three estuaries studied ranged from 3 days to 10 years (Table 1). For the Seine estuary, the age of the uppermost part of the sediment varied from a few days to a month, largely related to the unique behaviour of this system, i.e., high sediment supply and sedimentation rates, but only during the highest spring tides. On the Authie mudflat, where sedimentation is driven by the fortnightly cycle, the age of the top $1 \mathrm{~cm}$ of surface sediment was in the range of 1-10 days. For the Medway estuary, Cundy et al. (2005), using radionuclide methods, indicated a mean sedimentation rate of 4 mm.year ${ }^{-1}$ in the upper $13 \mathrm{~cm}$ of the cores; this value is consistent with a single surface lamina and the absence of physical structures in this layer.

Based on altimetric measurements, the percentage of preserved sediment (preservation rate) on the mudflat can be calculated: 
On the Medway mudflat, the annual sedimentation rate is not enough significant in order to calculate a preservation rate (table 2). On the Authie mudflat, the preservation rate is high: $90 \%$

(Table 2). This high preservation rate is consistent with the morphology of the bay: few erosion episodes are recorded in this system (Fig. 3). On the contrary, in the Seine estuary, the preservation rate is lower (50\%). This value implies that half of the fine sediment deposited on this mudflat during the year is stored temporally because of the erosion induced by current and waves. As a consequence, the lithology observed in the cores correspond to a discontinuous record, controlled by the turbidity maximum inputs and the erosion events (Fig. 3).

This paper demonstrates that high-resolution, high frequency and long term altimetric measurements can be used in order to better apprehend fast infilling mudflats. Most of the studies on intertidal mudflats deal with the sedimentary processes on the mudflat's surface, including studies based on altimetric measurements (Christies et al., 1999; Bassoulet et al., 2000; O’Brian et al., 2000; Andersen et al., 2002; Andersen et al., 2006). None of theses studies is concerned by the 418 lithological records in the mudflat's sediment. However many researchers are involved in recent or 419 ancient tidal rhytmites lithological records (e.g: Dalrymple et al., 1978; Tessier, 1993; Kvale et al., 420 1994; Archer, 1995; Tessier et al., 1995; Choi et Park, 2000; Stupples, 2002; Mazumder et Arima, 421 2005). This paper proposes a sampling strategy based on high resolution techniques that allow to 422 make the link between sedimentary processes at the mudflat's surface and the lithological recording 423 in depth (i.e. tidal rhythmites). Such sampling strategy brings new insights on the occurrence and 424 the preservation rate of tidal rhythmites on rapidly infilling intertidal mudflats. 
For estuarine intertidal mudflats, sedimentation and erosion processes are controlled by a complex combination of fine sediment availability, sediment properties, local morphology, hydrodynamics parameters (including tidal cycles, river flow, and wind-generated waves), and biological activity. These parameters shape the morphological evolution of intertidal mudflats at several time scales.

For this study, a combination of altimeter measurements at high resolution and high frequency over one year and collection of sediment cores along the survey led to a better understanding of the mechanisms controlling sedimentation and erosion at quasi-instantaneous (e.g., wind-generated erosion), semi-diurnal, and seasonal scales. For the three mudflats investigated, deposition and erosion occurred at the semi-diurnal tidal scale, whereas the sedimentation rhythms were driven either by fortnightly and lunar cycles. The analysis of the sedimentation rhythms :confirm that the Authie mudflat is in a typical sheltered environment, where the deposition of fine-grained material occurs on a fortnightly-scale; that the Medway mudflat is in a sediment-starved system that is dominated by the reworking of autochtonous material; and that the mudflat in the mouth of the Seine estuary is characterized by a unique pattern of sedimentation, in which sedimentation occurs only during the highest spring tides, when suspended sediment concentrations in the turbidity maximum are higher. Lithological analysis coupled to altimeter measurements demonstrates that the sedimentation is nearly continuous (following the neap-spring cycles) on the Authie Bay, while it is discontinuous on the Seine estuary: the sedimentation occurs at lunar scale only during highest spring tide while erosion of the deposited sediment is controlled by tidal currents and waves.

\section{Acknowledgements}

This study was carried out as part of the Seine-Aval French interdisciplinary research program (http://seine-aval.crihan.fr), supported by the following partners: the French Government, the HauteNormandie Region and the other Regions of the Paris basin, the Agence de l'Eau Seine-Normandie, and the industries of Haute-Normandie. This work also was supported by the franco-british Rimew Interreg IIIA program (http://info1.scitech.sussex.ac.uk/rimew) and the French national program PNETOX II. Data on 
454 wind speed and direction were provided by the CEFAS and IFREMER. The authors also would like to 455 express their gratitude to John Taylor (University of Sussex, U.K) for his helpful comments, Joël Saint Paul, 456 and Michel Cremer and Olivier Weber (University of Bordeaux, France) for SCOPIX analyses. Michel 457 Simon (University of Rouen) greatly assisted in the field work.

458 


\section{References}

459

460

461

462

463

464

465

466

467

468

469

470

471

472

473

474

475

476

477

478

479

480

481

482

483

484

485

486

487

488

489

490

491

492

493

494

495

Amos, C.L., 1995. Siliciclastic tidal flats, in: Perillo, G.M.E. (ed.). Geomorphology and Sedimentology of Estuaries. Developments in Sedimentology, 53. Amsterdam. Elsevier, pp. 273-306.

Andersen, T.J., Pejrup, M., Nielsen, A.A., 2006. Long-term and high-resolution measurements of bed level changes in a temperate, microtidal coastal lagoon. Mar. Geol., 226, 115-125.

Andersen, T.J., Pejrup, M., 2002. Biological mediation of the settling velocity of bed material eroded from an intertidal mudflat, the Danish Wadden Sea. Estuar. Coast. Shelf S., 54, 737-745.

Anthony, E.J., Dobroniak, 2000. Erosion and recycling of estuary-mouth dunes in a rapidly infilling macrotidal estuary, the Authie, Picardy, northern France, in: Pye, K., Allen, J.R.L. (eds), Coastal and Estuarine Environments. Sedimentology and Geoarchaelogy. Special publication of the Geological Society of London, 175, pp. 109-121.

Archer, A.W., Kuecher, G.J., Kvale, E.P., 1995. The role of tidal velocity asymmetries in the deposition of silty tidal rhythmites (Carboniferous, estern interior coal basin, USA). J. Sediment. Res., A65, 408-416.

Avoine, J., Allen, G.P., Nichols, M., Salomon, J.C., Larsonneur, C., 1981. Suspended sediment transport in the Seine estuary, France. Effect of man-made modifications on estuary-shelf sedimentology. Mar. Geol., 40, 119-137.

Bassoullet, P., Le Hir, P., Gouleau, D., Robert, S., 2000. Sediment transport over an intertidal mudflat: field investigations and estimation of fluxes within the "Baie de Marennes-Oleron" (France). Cont. Sh. Res., 20, 1635-1653.

Black, K.S., Paterson, D.M., Cramp, A., 1998. Sedimentary processes in the intertidal zone, The Geological Society, London, 410 pp.

Burd, F., 1989. Saltmarsh survey of Great Britain, Research and Survey in Nature Conservation, 17, Nature Conservancy Council, Peterborough.

Christie, M.C., Dyer, K.R., Turner, P., 1999. Sediment flux and bed-level measurements from a macrotidal mudflat. Estuar. Coast. Shelf S., 49, 667-688.

Choi, K.S., Park, Y.A., 2000. Late Pleistocene silty tidal rhythmites in the macrotidal flat between Youngjong and Youngyou Islands, west coast of Korea. Mar. Geol., 167, 231-241.

Cundy, A.B., Lafite, R., Taylor, J.A., Hopkinson, L., Deloffre, J., Charman R., Gilpin, M., Spencer, K., Carey, P.J., Heppell, C.M., Ouddane, B., De Wever, S., 2005. Sediment transfer and accumulation in two contrasting saltmarsh/mudflat systems: the Seine estuary (France) and the Medway estuary (UK). Hydrobiologia, accepted.

Coppens, A.B., 1981. Simple equations for the speed of sound in Neptunian waters. J. Accoust. Soc. Am., 69, 862-863.

Dalrymple, R.W., Knight, R.J., Lambiase, J.J., 1978. Bedforms and their hydraulic stability relationships in a tidal environment, Bay of Fundy, Canada. Nature, 275, 100-104.

Delo, E. A., Ockenden, M. C., 1992. Estuarine muds manual, v. SR 309, HR Wallingford. 
Deloffre, J., Lafite, R., Lesueur, P., Verney, R., Lesourd, S, Cuvilliez, A., Taylor, J, 2006. Interactions between intertidal mudflat and turbidity maximum in macrotidal estuarine context. Mar. Geol., 235, 151-164.

Deloffre, J., Lafite, R., Lesueur, P., Lesourd, S., Verney, R., Guézennec, L., 2005. Sedimentary processes on a fluvial estuarine mudflat: the macrotidal Seine example (France). Estuar. Coast. Shelf S., 64, 710-720.

Dyer, K. R., 1995, The typology of intertidal mudflats; in: Perillo, G.M.E. (ed.). Geomorphology and Sedimentology of Estuaries. Developments in Sedimentology, 53. Amsterdam. Elsevier, pp. 273-306.

Dyer, K.R., Christie, M.C., Feates, N., Fennessy, M.J., Pejrup, M., Van der Lee, W., 2000a. An investigation into processes influencing the morphodynamics of an intertidal mudflat, The Dollard Estuary, The Netherlands: I. Hydrodynamics and suspended sediments. Estuar. Coast. Shelf S., 50, 607-625.

Dyer, K. R., Christie, M. C., Wright, E. W., 2000b. The classification of intertidal mudflats. Cont. Shelf Res., 20, 1039-1060.

Fan, D., Guo, Y., Wang, P., and Shi, J.Z., 2006. Cross-shore variations in morphodynamic processes of an open-coast mudflat in the Changjiang delta, China:with an emphasis on storm impacts. Cont. Shelf Res., 26, 517-538.

Gouleau, D., Jouanneau, J.M., Weber, O., et Sauriau, P.G., 2000. Short- and long-term sedimentation on Montportail-Brouage intertidal mudflat, Marennes-Oléron Bay (France). Cont. Shelf Res., 20, 1513-1530.

Kvale, E.P., Fraser, G.S., Archer, A.W., Zawistoski, A., Kemp, N., McCough, P., 1994. Evidence of seasonal precipitation in Pennsylvian sediments of the Illinois Basin, Geology, 22, 331-334.

Kim, S.C., Friedrichs, C.T., Maa, J. P.Y., Wright, L.D., 2000. Estimating bottom stress in tidal boundary layer from acoustic doppler velocimeter data. J. Hydrol. Eng., 126, p. 399-406.

Kirby, R., Bleakley, R.J., Weatherup, S.T.C., Raven, P.J., and Donaldson, N.D., 1993. Effect of episodic events on tidal mudflat stability, Armillan Bay, Strangford Lough, Northern Ireland, in: Mehta, A.J. (Ed), Nearshore and Estuarine Marine Cohesive Sediment Transport, Coastal and Estuarine Studies, Vol. 42. Am. Geoph. U., Washington, DC, pp. 378-392.

Kirby, R., 1990. The sediment budget of the erosional intertidal zone of the Medway Estuary, Kent. Proceedings of the Geologists Association, 101, 63-77.

Le Hir, P., Ficht, A., Da Silva Jacinto, R., Lesueur, P., Dupont, J.P., Lafite, R., Brenon, I., Thouvenin, B. Cugier, P., 2001. Fine sedimentation transport and accumulations at the mouth of the Seine Estuary (France). Estuaries, 24, 950-963.

Lafite, R., Romaña, L.A., 2001. A man-altered macrotidal estuary: The Seine estuary (France): Introduction to the special issue. Estuaries, 24, 939.

Lesourd, S., Lesueur, P., Brun-Cottan, J.-C., Auffret, J.-P., Poupinet, N., Laignel, B., 2001. Morphosedimentary evolution of the macrotidal Seine estuary subjected to human impact. Estuaries, 24, (6B), p. 940-949. 
Lofi, J. Weber, O., 2001. SCOPIX - digital processing of X-ray images for the enhancement of sedimentary structures in undisturbed core slabs. Geo-Mar. Lett., 20, 182-186.

Mazumder, R.; and Arima, Z., 2005. Tidazl rhythmites and their implications. Earth Sci.-Rev., 69, 79-85.

Migeon, S., Weber, O., Faugeres, J.-C., Saint-Paul, J., 1999. SCOPIX: A new X-ray imaging system for core analysis. Geo-Mar. Lett.s, 18, 251-255.

O'Brien, D.J., Whitehouse R.J.S. Cramp, A., 2000. The cyclic development of a macrotidal mudflat on varying timescales. Cont. Shelf Res., 20, 1593-1619.

Pritchard, D., Hogg, A.J., Roberts, R., 2002. Morphological modelling of intertidal mudflats: the role of cross-shore tidal currents. Cont. Shelf Res., 22, 1887-1895.

Perillo, G.M.E., 1995. Definitions and geomorphologic classifications of estuaries, in: Perillo G.M.E. (Ed.), Geomorphology and sedimentology of estuaries. Developments in Sedimentology, 53. Amsterdam: Elsevier, pp. 17-47.

Pye, K., French, P.W., 1993. Targets for Coastal Habitat Recreation, A report for English Nature, Cambridge Environmental Research Consultants, Cambridge.

Schoellhamer, D.H., 1996. Anthropogenic sediment resuspension mechanisms in a shallow microtidal estuary. Estuar. Coast. Shelf S., 43 (5), 533-548.

Soulsby, R.L., 1995. Bed shear stress due to combined waves and currents. In Stive, M.J.F., de Vriend, H.J., Fredsoe, J., Hamm, L., Soulsby, R.L., Teisson, C. and Winterwerp, J.C. (Eds). Advances in coastal morphodynamics, Delft Hydraulics, 4, 4-23.

Stupples, P., 2002. Tidal cycles preserved in late Holocene tidal rhythmites, the Wainway Channel, Romney Marsh, southeast England. Mar. Geol., 110, 355-367.

Tessier, B., 1993. Upper intertidal rhythmites in the Mont-Saint-Michel Bay (NW France): perspectives for paleoreconstruction. Mar. Geol., 110, 355-367.

Tessier, B., Archer, A.W., Lanier, W.P. Feldman, H.R., 1995. Comparison of ancient tidal rhythmites (Carboniferous of Kansas and Indiana, USA) with modern analogues (the bay of Mont-Saint-Michel, France). Special Publications of the International Association of Sedimentologists, 24, pp. 259-271.

Verney, R., Deloffre, J., Brun-Cottan, J.C., and Lafite, R., 2007. The effect of wave-induced turbulence on intertidal mudflats: impact of boat traffic and wind. Cont. Shelf Res., in press, corrected proof.

Voulgaris, G., Trowbridge, J. H., 1998, Evaluation of the acoustic doppler velocimeter (ADV) for turbulence measurements. J. Atmos. Ocean. Tech., 15, 272-289.

Voulgaris, G., Meyers, S. T., 2004. Temporal variability of hydrodynamics; sediment concentration and sediment settling velocity in a tidal creek. Cont. Shelf Res., 24, 1659-1683.

West, M. S., West, J. R., 1991, Spatial et temporal variations in intertidal zone properties in the Severn estuary, UK, in: Elliott, M., Ducrotoy, J.P. (eds), Estuaries et Coasts, Alson et Alson, Fredensborg, pp. 25-30. 


\section{Caption (6 figures)}

Figure 1 : Location of the areas studied (modified from Cundy et al., 2005)
(A) Medway estuary (Kent, UK)
(B) Authie estuary (Pas-de-Calais, France)
(C) Seine estuary, (Normandy, France)

Figure 2 : Typical grain-size of the surface sediment on the studied mudflats,

Figure 3 : Annual bed-elevation on the intertidal mudflats of the studied estuaries

Figure 4 : Sedimentation rhythms: comparison between monthly bed level evolution and recorded lithology

A: Authie; B: Seine and C: Medway

E.S.: Erosion Surface

Figure 5: Semi-diurnal mechanisms; sedimentary and hydrodynamics condition during similar spring tide conditions. A: Authie (07/05/03); B: Seine (10/05/03) and C: Medway (10/04/05) Theses trends have been observed during several semi-diurnal surveys on each mudflat.

Figure 6 : Relationship between tidal range and maximal deposit thickness on the Authie and and the Seine mudflats

LRF : Low River flow

HRF : High River Flow 


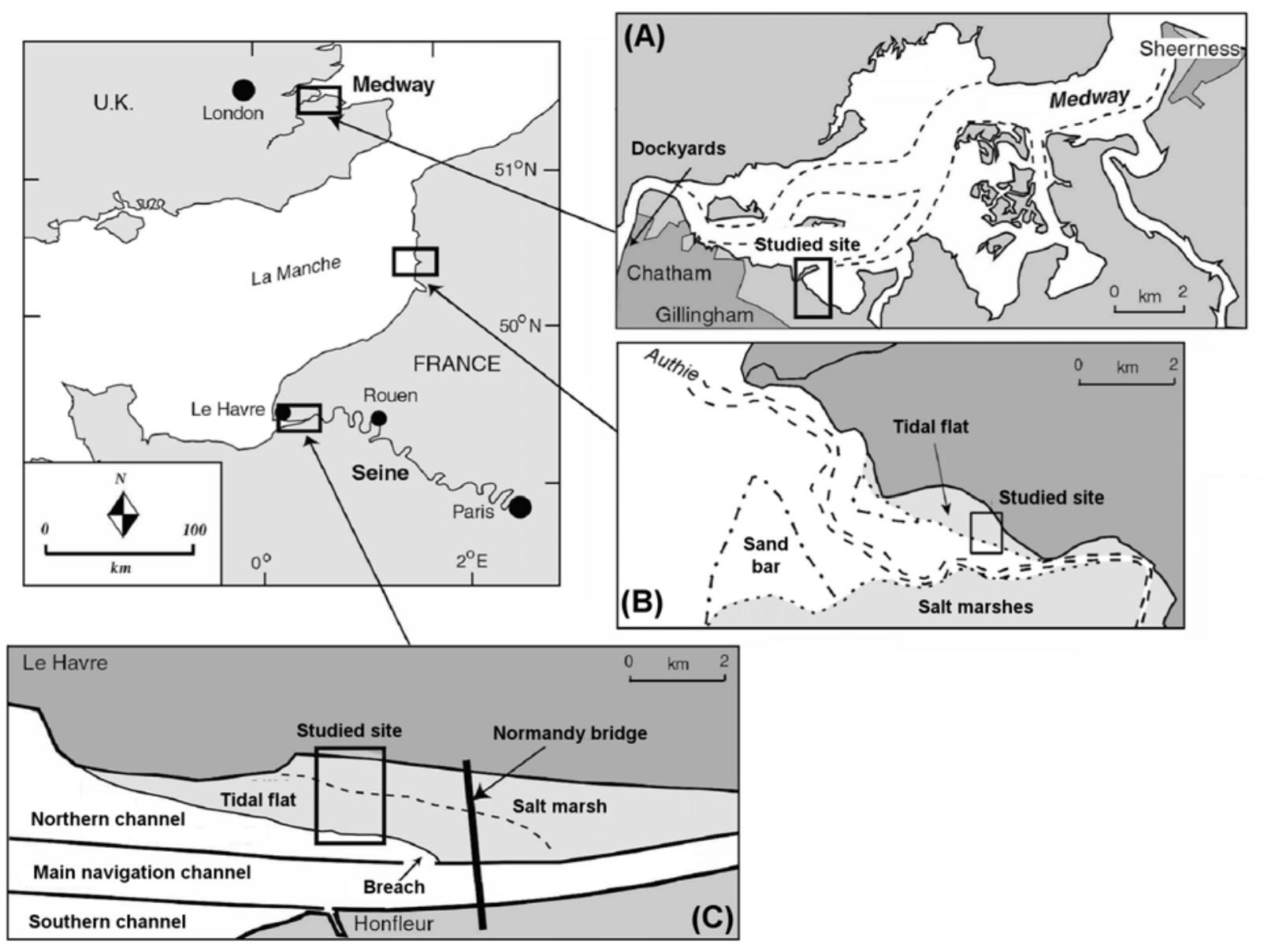

Figure 1 




Figure 2 




Figure 3 
A

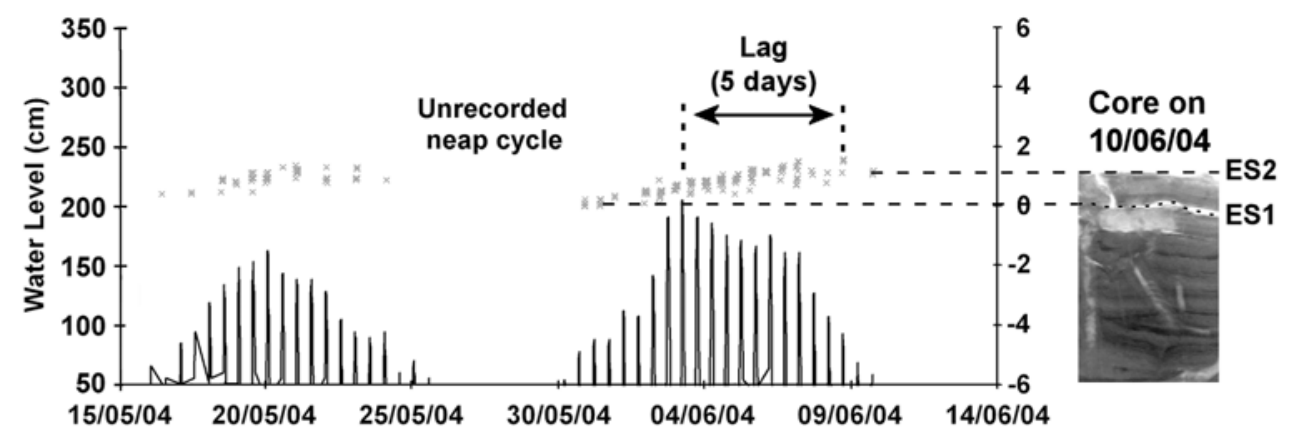

B

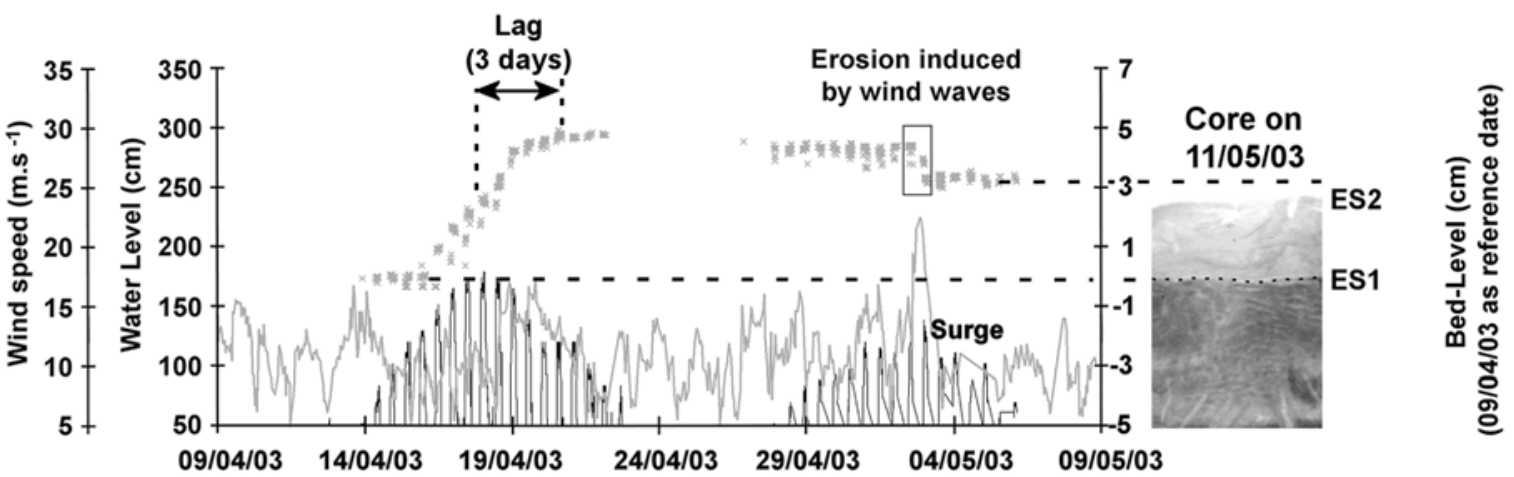

C

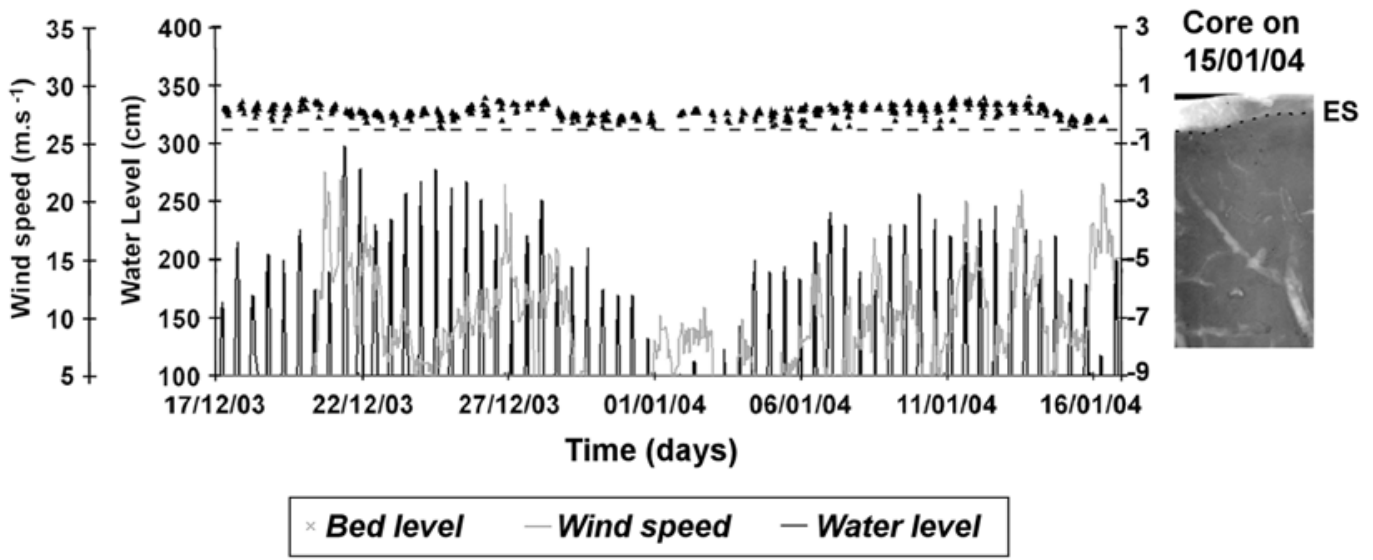

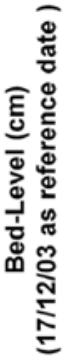

Figure 4 

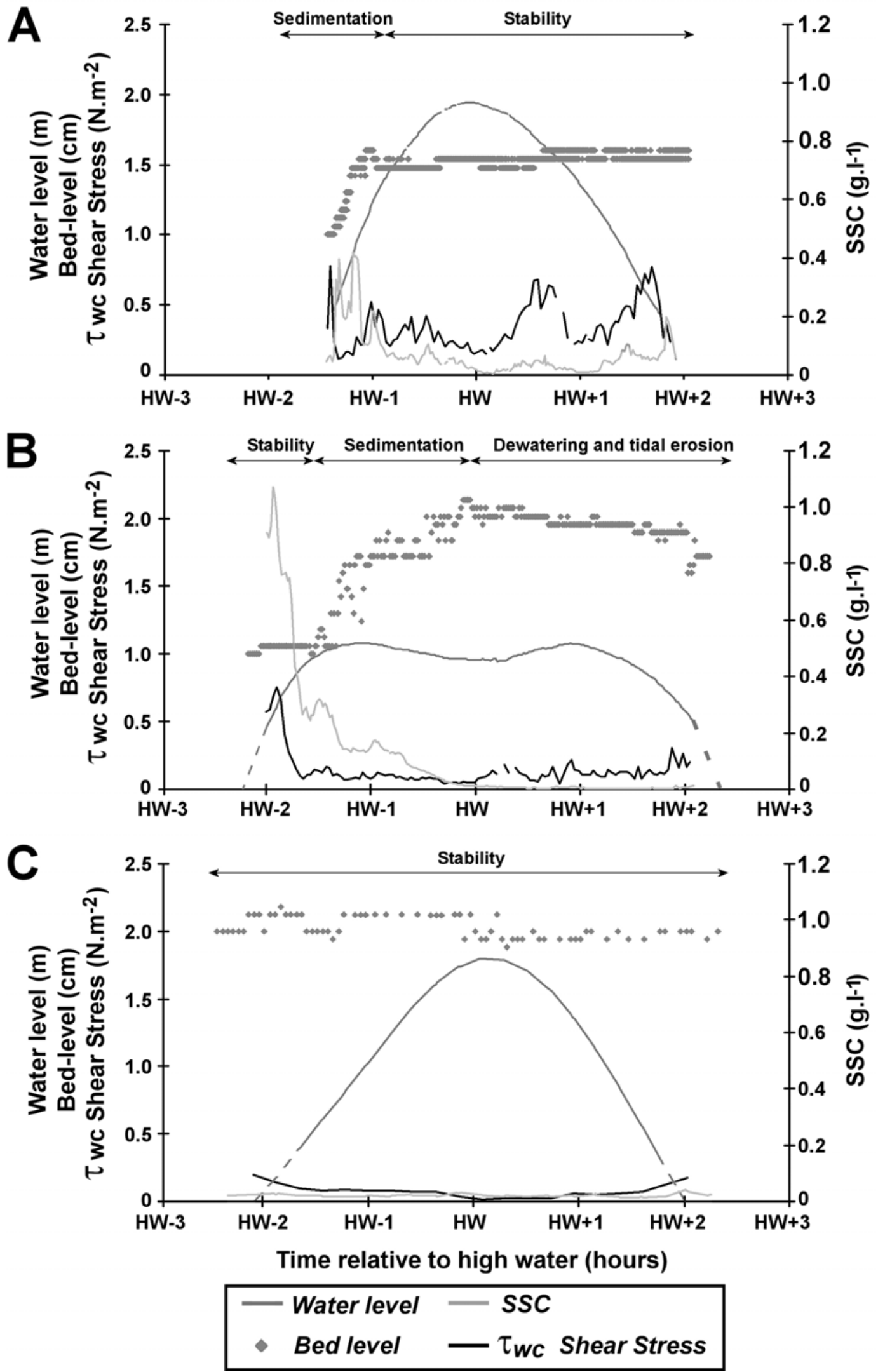

Figure 5 


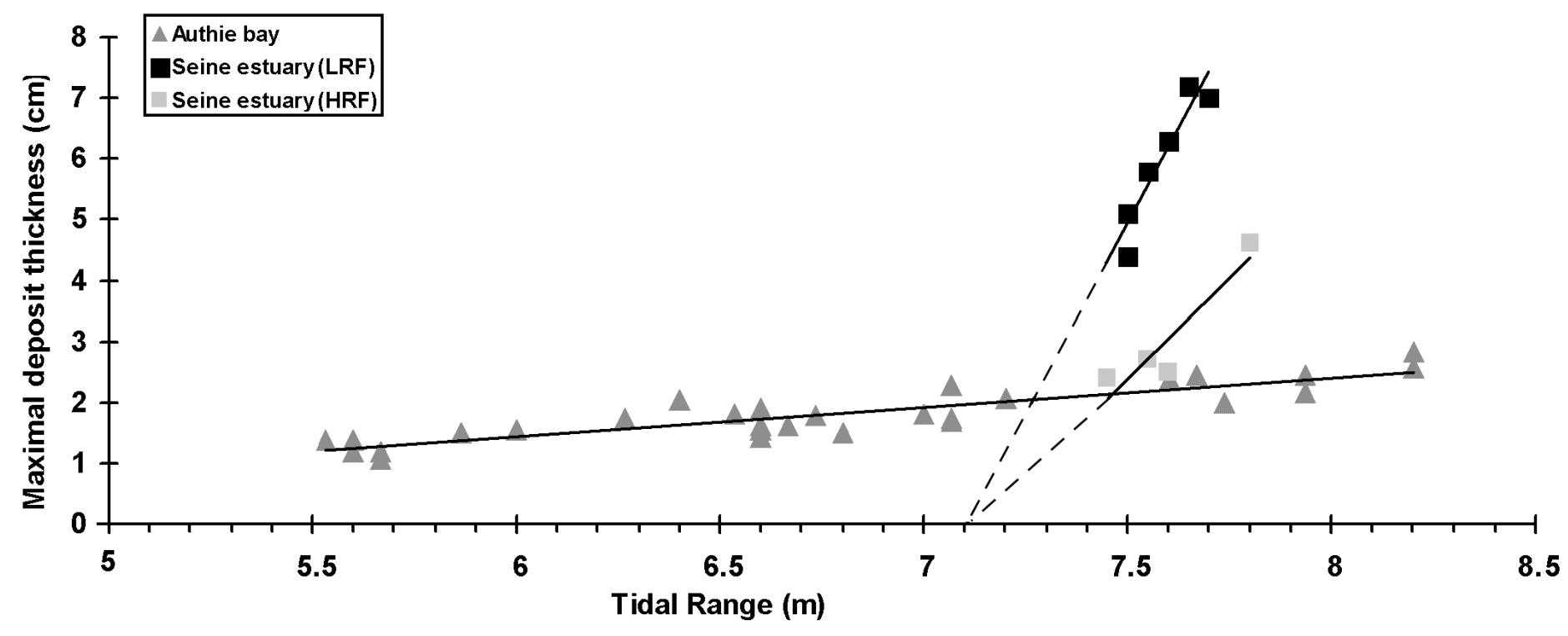

Figure 6 


\section{Caption (2 tables)}

Table 1 : Main characteristics of the studied mudflats (N/A: not available).

Table 2 : Comparison of the main sedimentological results on the studied mudflats. SD : semi-diurnal; FC: fortnightly cycle; LC: lunar cycle; TM: turbidity maximum 


\begin{tabular}{|c|c|c|c|c|}
\hline & & Seine & Authie & Medway \\
\hline \multirow{4}{*}{ 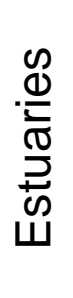 } & Mean river discharge $\left(\mathrm{m}^{3} \cdot \mathrm{s}^{-1}\right)$ & $430(200-2,000)$ & $10(4-15)$ & 35 \\
\hline & Annual solid discharge (tons) & 500,000 & N/A & N/A \\
\hline & Tidal range at the mouth $(\mathrm{m})$ & 6.0 to 8.0 & 6.0 to 8.5 & 5.1 to 5.6 \\
\hline & Catchment area surface $\left(\mathrm{km}^{2}\right)$ & 79,000 & 985 & 1,750 \\
\hline \multirow{4}{*}{$\begin{array}{l}\frac{n}{\pi} \\
\frac{\pi}{\underline{T}} \\
\frac{0}{2} \\
\sum\end{array}$} & Maximum bottom SSC $\left(\mathrm{g} . \mathrm{I}^{-1}\right)$ & -2.5 & 1.5 & 0.25 \\
\hline & $\begin{array}{l}\text { Maximum [Flood-Ebb] current velocities } \\
\qquad\left(\mathrm{m} \cdot \mathrm{s}^{-1}\right)\end{array}$ & {$[0.5-0.45]$} & {$[0.5-0.45]$} & {$[0.35-0.25]$} \\
\hline & Maximum Twc shear stress $\left(\mathrm{N} \cdot \mathrm{m}^{-2}\right)$ & 1.5 & 1 & 0.5 \\
\hline & Mean water temperature $\left({ }^{\circ} \mathrm{C}\right)$ & $5-20$ & $N / A$ & $4-22$ \\
\hline
\end{tabular}

Table 1 


\begin{tabular}{|c|c|c|c|}
\hline & Seine & Authie & Medway \\
\hline Morphology at the Mouth & Opened estuary & Protected Bay & Opened estuary \\
\hline Sediment Supply & Turbidity Maximum & $\begin{array}{c}\text { Resuspended sediment inside the } \\
\text { estuary }\end{array}$ & Low : Recycling in the estuary \\
\hline Forcing parameter(s) & $\begin{array}{l}\text { - Strongest Spring tides (TM } \\
\text { development) } \\
\text { - Wind (>15 m.s- } 1 \text { westerlies) }\end{array}$ & Tidal Cycles & - \\
\hline $\begin{array}{l}\text { Sedimentation rates at semi-diurnal scale } \\
\qquad(\mathrm{cm})\end{array}$ & 0.3 to 0.8 & 0.1 to 0.6 & - \\
\hline $\begin{array}{l}\text { Main sedimentation cycles (deposit } \\
\text { sequence) }\end{array}$ & Lunar & Fortnightly & None \\
\hline $\begin{array}{l}\text { Max. sedimentation during one deposit } \\
\text { episod }(\mathrm{cm})\end{array}$ & 8 & 5 & - \\
\hline Number of sedimentation episod/year & 7 to 10 & 15 to 22 & - \\
\hline Annual sedimentation rates $(\mathrm{cm})$ & 18 & 15 & 0 \\
\hline Preservation rates $(\%)$ & $50 \%$ & $90 \%$ & - \\
\hline $\begin{array}{l}\text { Typical Facies and Estimated duration } \\
\text { based on bed-level evolution }\end{array}$ & SD $\quad \begin{array}{r}\text { Lunar } \\
\text { cycle of } \\
\text { deposition }\end{array}$ SD 3 Days & 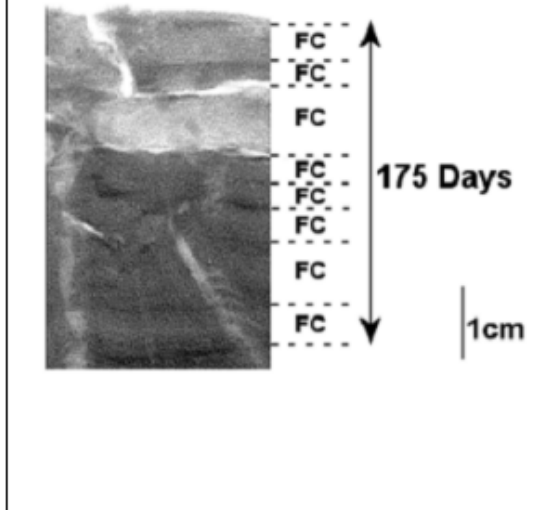 & Base on radionucleides \\
\hline
\end{tabular}

Table 2 
